\author{
Stawomir Judek \\ Krzysztof Karwowski \\ Mirostaw Mizan \\ Politechnika Gdańska \\ Wydziat Elektrotechniki i Automatyki
}

\title{
Diagnostyka i monitoring odbioru prądu z sieci trakcyjnej
}

\begin{abstract}
Dla zapewnienia bezpieczeństwa i niezawodności eksploatacyjnej transportu kolejowego kluczowe znaczenie techniczne ma uklad odbioru pradu z sieci jezdnej przez poruszajace sie pojazdy. Jego poprawne działanie zależy m.in. od prawidtowej regulacji zarówno sieci jezdnej, jak i odbieraka pradu. W artykule przedstawiono przeglad różnych metod $i$ urzadzeń diagnostyki i monitoringu trakcyjnych odbieraków pradu oraz sieci trakcyjnej, stosowanych przez zarzady transportu kolejowego. Omówiono strukturę $i$ wyniki eksploatacji wdrożonych rozwiqzań krajowych oraz wybranych układów eksperymentalnych i projektów badawczych. Przedstawiono wdrażany aktualnie skomputeryzowany $i$ działajacy $w$ petni automatycznie system monitoringu odbieraków pradu, oparty na bezstykowych metodach pomiaru.
\end{abstract}

\section{Wstęp}

Diagnostyka techniczna jest dynamicznie rozwijającą się dziedzina, której wykorzystanie w systemach transportowych prowadzi do zmniejszenia kosztów oraz podniesienia niezawodności i bezpieczeństwa eksploatacji. Dla prawidłowego działania zelektryfikowanego transportu szynowego konieczne jest utrzymanie we właściwym stanie technicznym zarówno infrastruktury, jak i taboru. Z punktu widzenia niezawodności eksploatacyjnej kluczowe znaczenie techniczne ma układ odbioru prądu z sieci jezdnej przez poruszające się pojazdy [21]. Wysoka jakość odbioru prądu zależy od ciagłości styku pomiędzy odbierakiem i siecią jezdna, uzyskiwanej poprzez regulację zarówno sieci jezdnej, jak i odbieraka prądu. Zbyt mały nacisk odbieraka na sieć jezdną, może prowadzić do powstawania przerw stykowych, natomiast zbyt duży - do nadmiernego wypierania sieci jezdnej, a w konsekwencji do ryzyka uszkodzeń mechanicznych i nadmiernego zużycia nakładek stykowych. Rozregulowana sieć jezdna może powodować: wzrost oscylacji przewodu, miejscowe zwiększenie zużycia przewodu jezdnego, a w skrajnych przypadkach - zniszczenie odbieraka. W celu ograniczenia tych niekorzystnych zjawisk, wprowadzane są nowe konstrukcje sieci jezdnej i odbieraków prądu, umożliwiające zwiększanie prędkości pojazdów $[1,3,9,11$, $22,25,32]$. Diagnostyka techniczna przyczynia się do poprawy bieżącego utrzymania sieci trakcyjnej i odbieraków prądu. Oprócz problemów ściśle technicznych mamy tu również do czynienia $\mathrm{z}$ dwoma podsystemami eksploatacyjnymi: siecią trakcyjną, będącą w gestii zarządu infrastruktury (Polskich Linii Kolejowych) i pojazdami eksploatowanymi przez różnych operatorów. Katedra Inżynierii Elektrycznej Transportu Politechniki Gdańskiej w ramach trwającej od kilkudziesięciu lat współpracy z PKP aktywnie uczestniczy w działaniach zmierzających do stworzenia kompleksowego systemu diagnostyki systemu odbioru prądu.

Pierwszym elementem tego systemu był utworzony $w$ latach dziewięćdziesiątych ubiegłego wieku system Diagnostyki Sieci Jezdnej DST, składający się z wagonów pomiarowych oraz stacjonarnych stanowisk do przetwarzania i analizy wyników [13], który jest nadal eksploatowany i stale modernizowany. Kolejnym elementem systemu było powstałe w Gdyni terenowe stanowisko pomiarowe do diagnostyki technicznej odbieraków prądu [30]. Do kontrolowania stanu technicznego odbieraków w trakcie przejazdu pojazdów, utworzony został eksperymentalny układ monitoringu dynamicznego oddziaływania odbieraka prądu na sieć trakcyjną [20]. Obecnie - przy współpracy z PKP Polskie Linie Kolejowe S.A. Biuro Energetyki - prowadzone są badania eksploatacyjne nowego stanowiska do monitorowania pantografów. W ubiegłych latach prowadzone były przez Katedrę liczne prace naukowo-badawcze w zakresie diagnostyki trakcyjnych odbieraków prądu [19], w szczególności dotyczące kontroli zawieszenia ślizgacza [31] oraz pomiaru wybranych parametrów czasowych w oparciu o analizę obrazu z kamery [18]. Aktualnie trwają prace nad wykorzystaniem analizy obrazu 3D do oceny stanu technicznego węglowej nakładki ślizgowej.

Stan diagnostyki systemu odbioru prądu przedstawiono schematycznie na rys. 1. Zarządy kolejowe muszą rozwijać monitorowanie i diagnostykę sieci i 
odbieraków, tak aby rozpoznawać ich stan i odpowiednio planować regulacje i remont $[6,7,17]$. Wprowadzane są nowe metody monitoringu i diagnostyki prowadzące do globalnego spojrzenia na całość funkcjonowania systemu trakcji elektrycznej $[8,17$, $24,28,29,33,34,36]$.

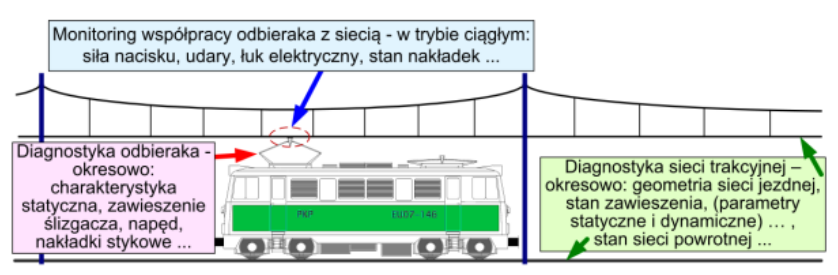

Rys. 1. Stan diagnostyki systemu odbioru prądu

W celu monitorowania stanu sieci jezdnej zarządy kolejowe wprowadzaja do eksploatacji systemy diagnostyki, z reguły instalowane na specjalnych wagonach $[5,8,13,28,33,34,37]$. Proces diagnostyczny obejmuje pomiary istotnych parametrów sieci, wykonywane automatycznie podczas przejazdu wagonu linią kolejowa, oraz następującą po tym analize zebranych wyników i ocenę stanu sieci. Wyposażenie pomiarowe i diagnostyczne wagonów jest unikalne najbardziej obiecujące są tu pomiarowe systemy optyczne, oparte na analizie obrazu z kilku kamer lub wykorzystujące skanery laserowe [5, 28,37].

Innym podejściem może być instalacja wybranych urządzeń pomiarowych na standardowym pojeździe [2]. Umożliwia to kontrolę współpracy sieć - pantograf za pośrednictwem bezkontaktowych czujników. Zebrana informacja o stanie technicznym może być przesłana drogą radiową do centrali sterowania ruchem.

Coraz częściej instalowane są w wybranych punktach linii kolejowej specjalistyczne przyrządy do oceny stanu technicznego np. odbieraka prądu przejeżdżającego pojazdu $[4,15,16,26]$.

Przykładowym rozwiązaniem jest eksperymentalne stanowisko monitoringu odbieraków [20] i np. „brama kontrolna” CATIEMONT (Catenary Interface Monitoring) zrealizowana przez zespół kilku firm.

W pracy [23] opisano rozwiązanie automatycznej kontroli wizualnej, w której wykorzystano kilka kamer do przechwytywania obrazu profili nakładek węglowych i oświetlacze laserowe do precyzyjnego zlokalizowania pantografu w przestrzeni. Analiza obrazów pozwala na określenie m.in.: grubości nakładki, ubytku materiału nakładki a także trendu zużycia nakładek z określeniem przewidywanego czasu do wymiany. Wadą tego rozwiązania jest skomplikowany układ kamer, oświetlaczy i ekranów świetlnych, stosowany w celu uzyskanie trójwymiarowej geometrii ślizgacza na podstawie obrazów dwuwymiarowych. Implikuje to niezwykle złożony algorytm obróbki danych wizyjnych.
Innym rozwiązaniem jest system Pancam [14], w którym analizy oparte są na dwuwymiarowym przetwarzaniu obrazu pantografów. System jest prostszy i mniej funkcjonalny niż opisywany w [23]. Wadą tego rozwiązania jest konieczność stosowania ekranów, zwiększających kontrasty pomiędzy zarysem pantografu a pozostałymi elementami fotografowanej sceny. W wyniku przeprowadzonych prób średnio w $20 \%$ zebranych danych nie było możliwe postawienie poprawnej diagnozy stanu technicznego odbieraka prądu.

Jednym ze sposobów automatycznego monitorowania uszkodzenia nakładek węglowych jest wykorzystanie komór ciśnieniowych lub światłowodów umieszczonych wewnątrz nakładki tak, że jej zużycie lub uszkodzenie powoduje rozszczelnienie komory ciśnieniowej lub uszkodzenie włókien optycznych. Spadek ciśnienia, bądź utrata ciągłości światłowodu stanowi informację diagnostyczną o stanie nakładki $[10,12]$. Sposób ten wymaga stosowanie specjalnej konstrukcji nakładek, odbieraków i pokładowych układów diagnostycznych. Wadą jest wykrywanie tylko całkowitego uszkodzenia nakładki.

W literaturze można również odnaleźć systemy szwedzki oraz włoski, w których monitoring stanu nakładek ślizgowych odbywa się na liniach dużych prędkości w normalnych warunkach eksploatacyjnych $(200 \mathrm{~km} / \mathrm{h})$. Sa to jednak systemy nastawione na wykrycie całkowicie zniszczonych nakładek. Brak jest nawet wskazania, czy do diagnostyki wykorzystywane są metody rozpoznawania obrazów.

\section{Krajowy system diagnostyki sieci trakcyjnej}

Diagnostyka sieci trakcyjnej na liniach kolejowych w Polsce opiera się w głównej mierze na wykorzystaniu systemu DST [13]. W jego skład weszły wagony pomiarowe oraz stacjonarne stanowiska do przetwarzania danych pomiarowych, rozmieszczone w regionalnych sekcjach Spółki PKP Energetyka.

System DST został zaprojektowany do realizacji diagnostyki dynamicznej, uwzględniającej współpracę odbieraka prądu i sieci jezdnej w warunkach eksploatacyjnych, tzn. podczas przejazdu wagonu przez kontrolowany odcinek linii kolejowej. W ograniczonym zakresie może być wykorzystywany do pomiarów statycznych. W najnowszej generacji systemu, oznaczonej symbolem DST2000, realizowane są - z rozdzielczością co $1 \mathrm{~m}$ - pomiary: odsuwu i wysokości zawieszenia sieci jezdnej, napięcia sieci trakcyjnej, przebytej drogi i prędkości wagonu oraz ruchów pudła wagonu - w celu programowej kompensacji ich wpływu na pomiar odsuwu i wysokości. Ponadto wykrywane są: niewłaściwie wyregulowane rozjazdy sieciowe, udary odbieraka prądu, przerwy styku odbieraka prądu z siecią jezdną - wraz z pomiarem ich czasu oraz konstrukcje wsporcze i rezonatory torowe SHP. 
Pomiary wszystkich parametrów wykonywane są automatycznie podczas przejazdu diagnostycznego i rejestrowane w postaci plików w komputerze pokładowym. Ponadto rejestrowany jest obraz wizyjny współpracy sieci jezdnej z odbierakiem. Nakładane tekstowo na rejestrowany obraz wartości położenia, czasu i wartości podstawowych mierzonych parametrów, umożliwiają łatwą synchronizację zapisu video z plikiem wyników pomiarowych. Zapis wizyjny może być wykorzystany do oceny geometrii sieci w sytuacjach wattpliwych, np. przy lokalnie złożonym układzie przewodów.

Zarejestrowane dane pomiarowe są przetwarzane w programie analizy wyników $-\mathrm{z}$ reguły na stacjonarnych stanowiskach przetwarzania danych, co umożliwia bardziej efektywne wykorzystanie wagonów pomiarowych. Oprogramowanie realizuje różne formy analizy i prezentacji wyników - tekstowo, graficznie, w postaci raportów zwykłych i porównawczych - $\mathrm{z}$ wynikami archiwalnymi, a także $\mathrm{w}$ ujęciu statystycznym. Utworzone oprogramowanie systemu DST, pionierskie $\mathrm{w}$ zastosowaniu $\mathrm{z}$ zakresu trakcji elektrycznej, celnie wpisało się w powstały w późniejszym okresie standard dla programów o takim przeznaczeniu [13]. W celu ułatwienia przeglądania raportów skompresowane dane diagnostyczne są prezentowane w punktach podwieszenia. Analogiczne rozwiązania stosowane są w innych zarządach kolejowych, np. [37]. Podstawowy sposób prezentacji wyników w programie analizy danych przedstawiono na rys. 2 . W górnej części ekranu znajduje się wykres wysokości zawieszenia przewodów jezdnych, w dolnej - wykres ich odsuwu poziomego w funkcji drogi, na tle linii wskazujących granice wartości normatywnych. Dodatkowe znaczniki wskazują punkty szczególne sieci np. punkty podwieszenia, rozjazdy sieciowe oraz wykryte stany niewłaściwej współpracy odbieraka z siecią np. przerwy stykowe, udary.

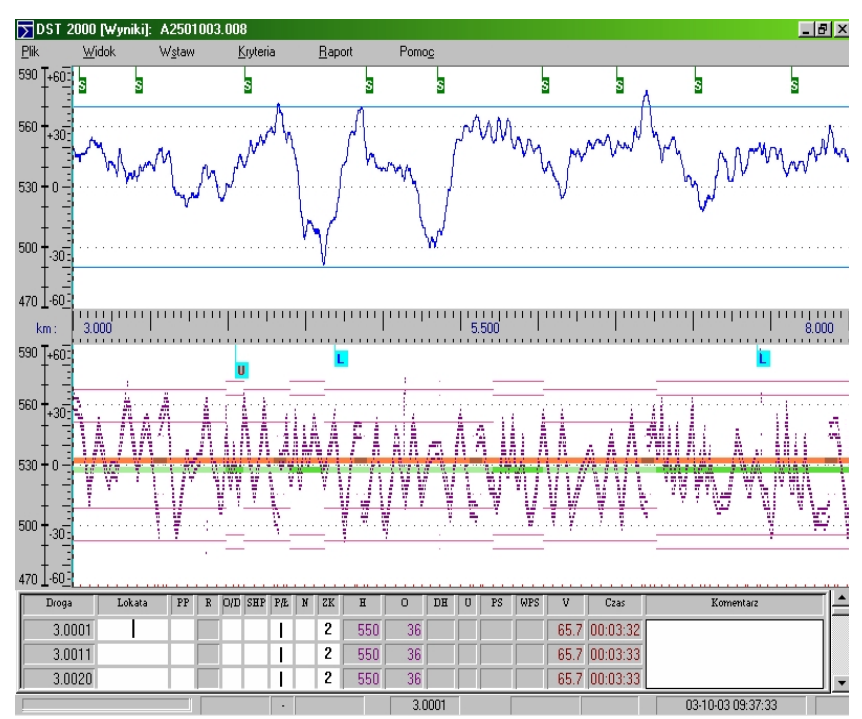

Rys. 2. Ekspozycja wyników pomiarów w systemie DST
Wieloletnia eksploatacja systemu DST wskazuje, że realizowana przy jego użyciu diagnostyka sieci pozwala skutecznie wykrywać usterki występujące na sieci. Należy podkreślić, że system DST wykorzystuje stykowe metody pomiaru, oparte na zastosowaniu na wagonie specjalnego pomiarowego odbieraka prądu. Wynika to częściowo z zakresu diagnostyki, jak i ze stanu techniki w chwili powstawania wagonów pomiarowych. W przypadku tworzenia nowej generacji systemu wskazane byłoby wykorzystanie nowoczesnych bezstykowych metod do diagnostyki statycznej parametrów geometrycznych sieci. Zwiększyłoby to możliwości i efektywność wykorzystania systemu przy budowie nowych lub przebudowie istniejących sieci. Szczególnie obiecujące wydaje się wykorzystanie czujników i dalmierzy laserowych oraz szybkich kamer 3D o wysokiej rozdzielczości [8, 35, 38].

\section{Diagnostyka odbieraków prądu}

Dla oceny stanu technicznego odbieraków prądu dotychczas są stosowane w kraju ręczne metody pomiaru, przy wykorzystaniu odpowiednich przyrządów pomiarowych. W praktyce pomiar istotnych parametrów odbywa się tylko podczas przeglądów kontrolnych lokomotyw, a stosowane metody pomiarowe sa czasochłonne, zaś w przypadku niektórych własności odbieraka - np. płynności ruchu przy podnoszeniu lub opuszczaniu - ocena ma charakter całkowicie subiektywny.

\section{Wyznaczanie charakterystyki statycznej odbieraka}

Czynnikiem, mającym największy wpływ na prawidłową współpracę odbieraka prądu $\mathrm{z}$ siecią jezdna, jest siła nacisku odbieraka na sieć. Konieczne jest utrzymanie wartości siły w przedziale określonym normami w całym roboczym zakresie wysokości uniesienia odbieraka. Dla realizacji automatycznego wyznaczania charakterystyki statycznej odbieraka prądu opracowano i wdrożono na terenie lokomotywowni w Gdyni terenowe stanowisko diagnostyczne [30]. Pomiar realizowany jest podczas przejazdu lokomotywy $\mathrm{z}$ niewielką prędkością $v$ - poniżej $10 \mathrm{~km} / \mathrm{h}$ - przez specjalnie wyprofilowane $\mathrm{w}$ osi pionowej przęsła sieci jezdnej, wyposażone w zestaw czujników pomiarowych. W układzie mierzone jest uniesienie przewodu jezdnego pod wpływem siły nacisku odbieraka - pomiar realizowany jest zatem metodą pośrednią. Wyprofilowanie sieci na odcinku pomiarowym $\mathrm{w}$ osi pionowej pozwala uzyskać zmianę uniesienia odbieraka podczas pomiaru, obejmującą cały roboczy przedział wartości wysokości, w jakim - zgodnie z normami - winna być kontrolowana siła nacisku statycznego. Odcinek pomiarowy obejmuje dwa sąsiednie przęsła zawieszenia; w pierwszym $\mathrm{z}$ nich wysokość zawieszenia przewodu maleje, w drugim rośnie. Pomiar uniesienia przewodu $\Delta h$ realizowany jest nieza- 
leżnie na obydwu odcinkach - na każdym w przybliżeniu w połowie przęsła zawieszenia - dzięki czemu możliwe jest również wyznaczenie siły tarcia w przegubach mechanizmu odbieraka. Zastosowano czujniki laserowe o zakresie pomiarowym ok. $20 \mathrm{~cm}$ i rozdzielczości rzędu 0,1 mm. Mierzone jest również aktualne położenie pojazdu na odcinku pomiarowym za pośrednictwem laserowego miernika odległości o zakresie pomiarowym rzędu kilkuset metrów. Sygnały ze wszystkich czujników pomiarowych, poprzez komputer pomiarowy umieszczony przy torze i układy bezprzewodowej transmisji danych WLAN (ang. Wireless Local Area Network), trafiają do centralnego stanowiska diagnostycznego $\mathrm{w}$ budynku lokomotywowni, gdzie są przetwarzane przy pomocy dedykowanego oprogramowania. Podsystem wizyjny, obejmujący: kamery, monitor TV, rejestrator obrazu i bezprzewodowe łącze nadawczo-odbiorcze, ułatwia obsłudze sterowanie procesem pomiarowym i identyfikację pojazdu i diagnozowanego odbieraka.

Rozmieszczenie głównych elementów stanowiska przestawiono na rys. 3 .

a)

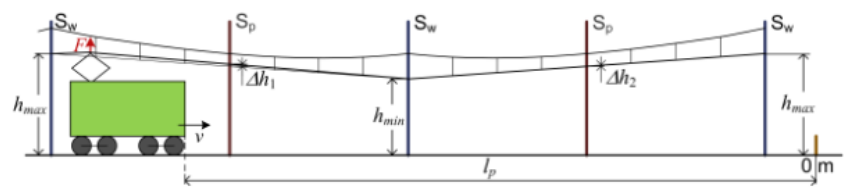

b)

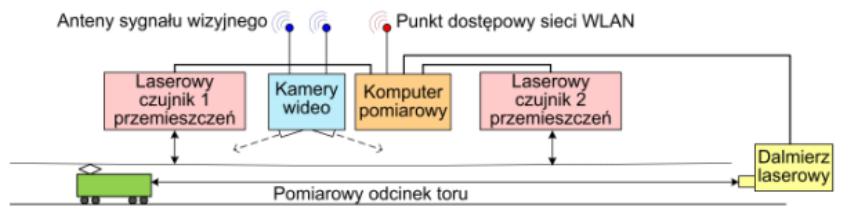

Rys. 3. Struktura i wyposażenie stanowiska pomiarowego: a) wyprofilowany odcinek sieci jezdnej, gdzie: $S_{w}-$ słupy wsporcze sieci, $\mathrm{S}_{\mathrm{p}}$ - słupy pomiarowe z zamontowanymi czujnikami pomiaru przemieszczenia przewodu wraz $\mathrm{z}$ osprzętem, $h_{\max }$ - maksymalna wysokość robocza odbieraka, $h_{\min }$ - minimalna wysokość robocza odbieraka; b) urządzenia pomiarowo-rejestrujące stanowiska

Wyznaczana siła może być określona ogólnym wzorem:

$$
F=f(l, k) \cdot \Delta h,
$$

gdzie: $\Delta h-$ zmierzone uniesienie przewodu jezdnego, $l$ - odległość pomiędzy odbierakiem prądu a punktem pomiarowym, $k$-współczynnik uwzględniający m.in. elastyczność sieci.

Ponieważ funkcja $f$ ma charakter nieliniowy i zależny od konstrukcji sieci jezdnej w obszarze szerszym niż odcinek pomiarowy, zastosowano metode empirycznego jej wyznaczenia i tabelarycznego umieszczenia w programie analizy wyników. Program pozwala obejrzeć wyznaczone charakterystyki w postaci wykresów oraz tabel, generuje także wydruki raportów w różnych formach.

Na rys. 4 przedstawiono przykładowe zestawienie porównawcze charakterystyk dla wybranej lokomotywy, pochodzących z pomiaru ręcznego i z pomiaru przy użyciu stanowiska diagnostycznego. Uzyskano dobrą zbieżność wyników dla obydwu metod pomiaru. Charakterystyki wyznaczane automatycznie przy pomocy tego stanowiska wykazują błędy mieszczące się zazwyczaj w paśmie $\pm 5 \%$. Jedynie dla wysokości powyżej 5,8 m zdarzają się nieco większe błędy. W tej strefie wysokości odbierak znajduje się w dużej odległości od czujnika, zatem sygnał roboczy ma mała wartość; w tych warunkach amplituda sygnału zakłócenia np. od ruchu przewodu wywołanego wiatrem może go nawet przewyższać. Ten zakres wysokości ma jednak mniejsze znaczenie eksploatacyjne. Proponowana metoda pozwala z dobrą dokładnością na wykrycie niesprawnych odbieraków, które powinny być na nowo wyregulowane lub naprawione.

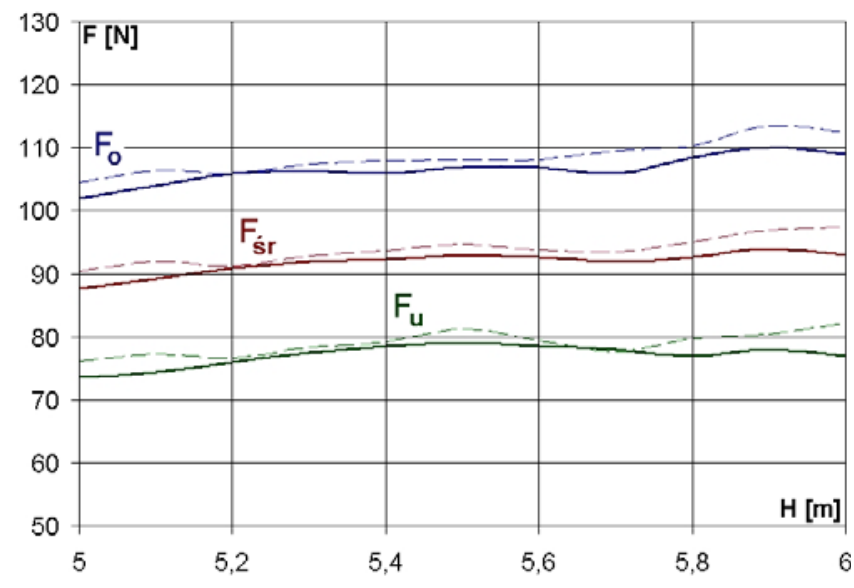

Rys. 4. Przykładowe charakterystyki statyczne rzeczywistego odbieraka wyznaczone przy pomocy stanowiska pomiarowego (linie cieńsze przerywane) oraz zmierzone ręcznie przy pomocy dynamometru (lnie grubsze ciagłe), gdzie $F_{o}, F_{u}$ - siła nacisku odbieraka odpowiednio przy zmniejszaniu i zwiększaniu się wysokości, $F_{s}$ - wartość średnia, $H$ - wysokość uniesienia odbieraka

\section{Kontrola zawieszenia ślizgacza}

Ważnym elementem konstrukcyjnym odbieraka dla jego poprawnej współpracy dynamicznej z siecią jest układ zawieszenia ślizgacza. Schemat kinematyczny węzła zawieszenia ślizgacza odbieraka prądu przedstawiono na rys. 5 .

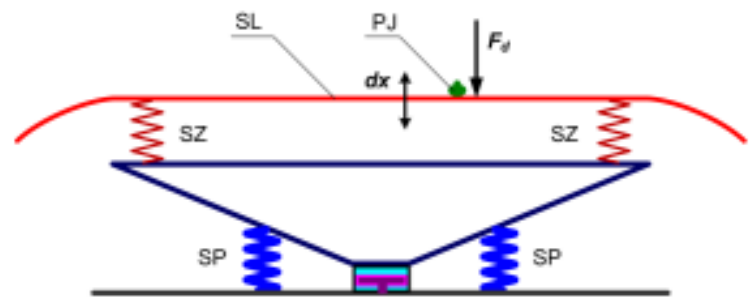


Rys. 5. Dynamiczna współpraca sieci z odbierakiem prądu, gdzie: $F_{d}$ - dynamiczna siła stykowa, $d x$ - przemieszczenie ślizgacza, SL - ślizgacz, PJ - przewód jezdny sieci trakcyjnej, SZ - sprężyny zawieszenia ślizgacza, SP - sprężyny unoszące odbierak

Zmienna w czasie dynamiczna siła stykowa $F_{d}$, związana z ruchem pojazdu, powoduje - dzięki ugięciu sprężyn zawieszenia - przemieszczanie się pionowe ślizgacza. Poprawnie działający układ zawieszenia ślizgacza zapewnia ciągłość jego styku z przewodem jezdnym oraz niweluje dynamiczne oddziaływanie odbieraka na sieć jezdną. Uszkodzenie sprężyn zawieszenia lub zatarcie przegubów może powodować pojawianie się przerw stykowych i udary w punktach zawieszenia sieci jezdnej. Kryterium oceny sprawności węzła zawieszenia jest wartość tzw. statycznej elastyczności zawieszenia - ugięcie $d x$ pod wpływem określonej siły $F$, czyli wartość $d x / F$. Pomiar tego parametru w eksploatacji jest kłopotliwy i często zaniedbywany.

Przeprowadzone badania symulacyjne i laboratoryjne na modelach fizycznych sieci i odbieraka wykazały, że układ sieć-odbierak, pobudzony udarowo siła zewnętrzną, reaguje drganiami o określonym przebiegu czasowym i charakterystycznym rozkładzie widmowym. Rozstrzygające znaczenie ma tu fakt wyraźnej różnicy między częstotliwościami drgań własnych sieci, konstrukcji odbieraka (sprężyny SP) i układu zawieszenia ślizgacza (sprężyny SZ). W zależności od sprężystości elementów i sił tarcia $\mathrm{w}$ zawieszeniu ślizgacza, związanych z jego aktualnym stanem technicznym, składowa częstotliwości drgań własnych tego układu pojawia się w rozkładzie widmowym drgań całego układu sieć-odbierak w różnym stopniu. Przyjęto zatem, że analiza widmowa tych drgań może być wykorzystana do celów diagnostycznych [31]. Dla eksperymentalnej weryfikacji tej tezy zbudowano stanowisko badawcze na terenie lokomotywowni w Gdyni - wykorzystano odcinek sieci półskompensowanej $\mathrm{z}$ jednym przewodem jezdnym, zawieszonej pomiędzy dwoma słupami wsporczymi, z dodatkowym słupem w połowie przęsła, na którym zainstalowano układy: pomiarowy oraz pobudzający drgania. Do rejestracji drgań układu odbierak-sieć wykorzystywano akcelerometr i żyroskopowy czujnik prędkości. Szkic konstrukcyjny stanowiska przedstawiono jest na rys. 6 .

Badania, mające na celu weryfikację przyjętej metody diagnostycznej, przeprowadzono na odbieraku typu AKP4E. Badano odbierak w pełni sprawny oraz odbierak z zablokowanym zawieszeniem ślizgacza. Zaobserwowano wyraźne różnice w wynikach przy odbieraku sprawnym i uszkodzonym dla obydwu stosowanych czujników - większe w przypadku czujnika żyroskopowego. Przykładowe wyniki pomiarów prędkości drgań dla odbieraka sprawnego i uszkodzonego pokazano na rys. 7 .

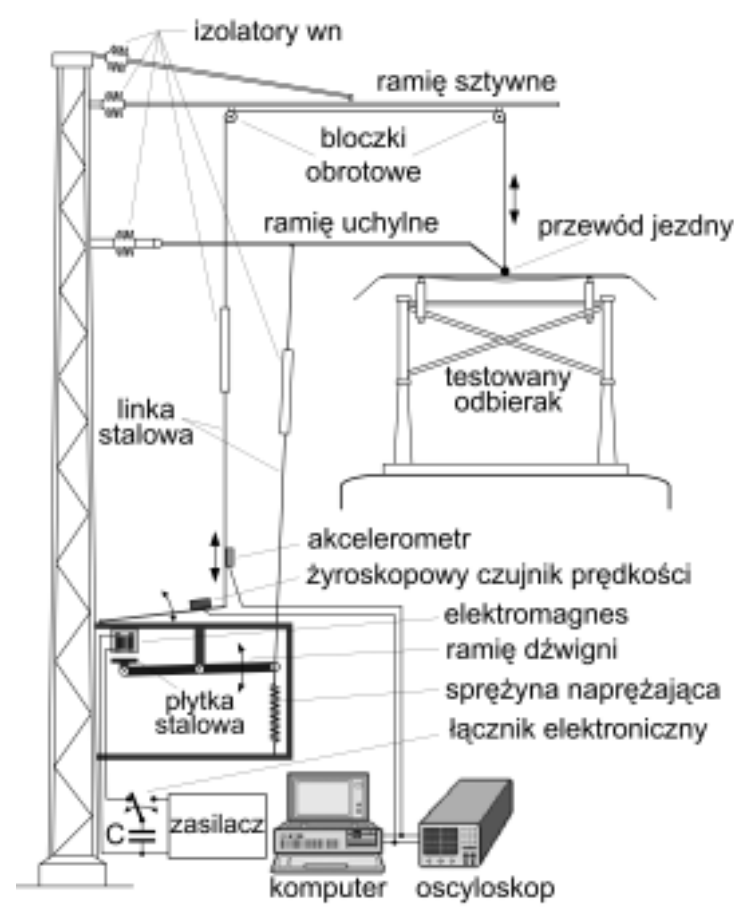

Rys. 6. Konstrukcja eksperymentalnego terenowego stanowiska do badania stanu zawieszenia ślizgacza
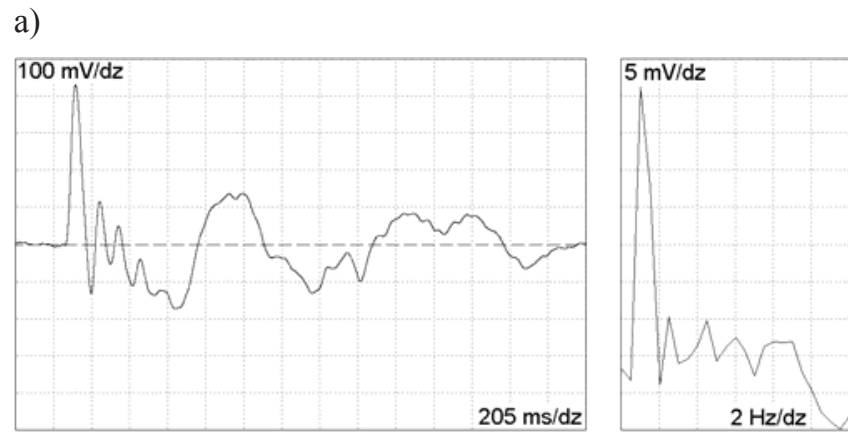

b)
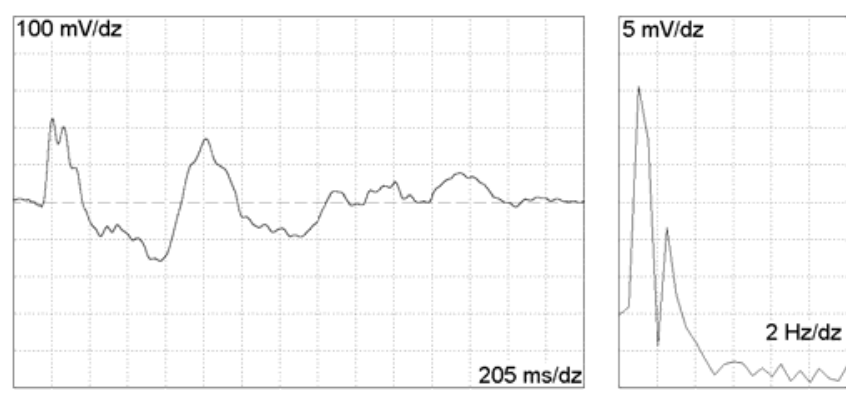

Rys. 7. Przebieg i rozkład widmowy sygnału prędkości drgań ślizgacza i sieci przy: a) poprawnie funkcjonującym zawieszeniu; b) zablokowanym mechanicznie zawieszeniu

Jako kryterium diagnostyczne można tu przyjąć stosunek amplitudy składowej podstawowej, związanej z częstotliwością drgań własnych sieci (ok. $1 \mathrm{~Hz}$ ) do amplitudy składowej związanej z częstotliwością drgań własnych układu zawieszenia ślizgacza (ok. 9 $\mathrm{Hz}$ ), która uwidacznia się tylko przy zawieszeniu sprawnym. Uzyskano wysoką powtarzalność wyników. Istotną zaletą metody jest brak konieczności wprowadzania pojazdu do hali i wchodzenia personelu na dach pojazdu. 


\section{Badanie napędu powietrznego odbieraków}

Diagnostyka techniczna lokomotyw obejmuje swym zakresem także badanie napędu powietrznego odbieraków. W dokumentach normatywnych, określających wymagania stawiane odbierakom prąu i metodykę ich badania, określa się, że ruch pionowy ślizgacza przy podnoszeniu i opuszczaniu za pomoca napędu powietrznego powinien odbywać się płynnie, bez zatrzymań i gwałtownych zmian prędkości, a jego dojście do przewodu i opadanie powinno się odbywać bez uderzeń. W celu umożliwienia wymiernej oceny stanu napędu odbieraków zdefiniowano miary parametrów czasowych, takie jak: czas podnoszenia, czas opuszczania oraz czas odłączenia się styku ślizgacza, i określono dla nich odpowiednie wartości graniczne. Podjęto więc próbę realizacji automatycznego stanowiska pomiarowego, opartego na metodzie wizyjnej, w celu zwiększenia dokładności i skrócenia czasu pomiaru w stosunku do stosowanych obecnie metod ręcznego pomiaru [18]. W skład eksperymentalnego stanowiska wchodzą: kamera, znaczniki pozycji, komputer klasy PC wyposażony $\mathrm{w}$ kartę akwizycji obrazu, karta wejść/wyjść cyfrowych oraz dedykowane oprogramowanie.

Pomiar opiera się na rejestracji ruchu odbieraka za pomocą kamery. Lokalizacja przyjętych charakterystycznych znaczników obrazu - w przeprowadzonym eksperymencie były to specjalnie usytuowane na stanowisku znaczniki pozycji oraz otwór konstrukcyjny ślizgacza - i śledzenie zmian odległości między nimi, pozwala określić czasy odłączania się ślizgacza od przewodu jezdnego, czas opuszczania oraz czas podnoszenia (rys. 8). Dodatkową zaletą metody jest możliwość sprawdzenia, zgodnie z wymaganiami normy, płynności ruchu odbieraka i jego łagodnego dojścia do przewodu jezdnego lub do gumowych odbojów poprzez sporządzenie i analizę wykresu zmian wysokości uniesienia odbieraka w funkcji czasu. W praktyce eksploatacyjnej ocena taka jest efektem subiektywnej obserwacji ruchu odbieraka. Badania w warunkach laboratoryjnych oraz eksploatacyjnych potwierdziły skuteczność działania układu. Maksymalne błędy pomiaru czasu były ponad dwukrotnie mniejsze od dopuszczonego przez normę, a programowa analiza parametrów ruchu odbieraka pozwalała wykryć stany niewłaściwe jego napędu. Zastosowanie metody wizyjnej nie wymaga montażu żadnych urządzeń na pojeździe.

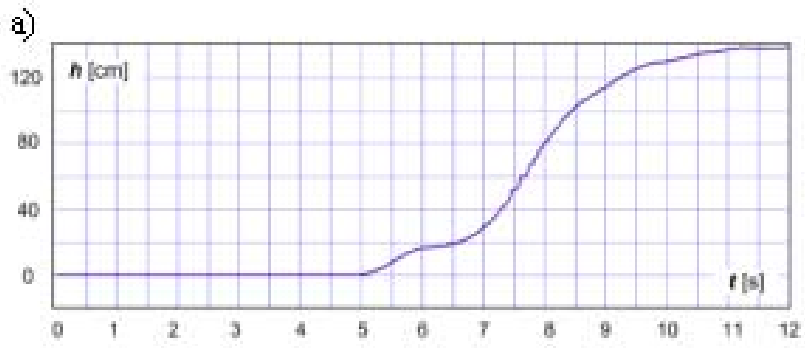

b)

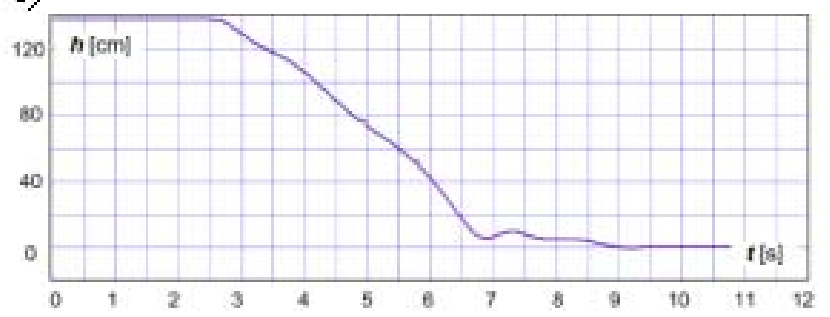

Rys. 8. Przykładowy przebieg zmian wysokości odbieraka: a) przy opadaniu; b) przy podnoszeniu, gdzie $h$ oznacza zmianę wysokości względem znaczników

\section{Monitoring odbieraków prądu}

Stany rozregulowania lub nawet uszkodzenia odbieraków prądu, zagrażające ich poprawnej współpracy z siecią jezdną, mogą powstać już po wyjeździe pojazdu z lokomotywowni. Niezbędne jest zatem kontrolowanie stanu technicznego odbieraków w trakcie przejazdu pojazdów w wybranych miejscach linii kolejowej o dużym natężeniu ruchu. Układ monitoringu odbieraków prądu pozwala wykryć ich niesprawność w warunkach ruchowych na linii kolejowej [19]. Działanie układu opiera się na kontroli dynamicznego oddziaływania odbieraków na sieć trakcyjną, w celu wykrycia egzemplarzy o niewłaściwej sile nacisku. Po przeprowadzeniu eksploatacji próbnej stanowiska w wersji eksperymentalnej, która potwierdziła słuszność przyjętych założeń i wybranych metod pomiaru, podjęto prace - będące aktualnie w końcowej fazie - nad opracowaniem i wdrożeniem jego wersji użytkowej dla PKP PLK SA.

Drugim ważnym eksploatacyjne zagadnieniem jest kontrola stanu nakładek ślizgowych. Obecna technika stwarza tu duże możliwości diagnostyczne poprzez analizę obrazu 3D.

Monitoring dynamicznego oddziaływania odbieraka prądu na sieć trakcyjną

Odbierak prądu przemieszczającego się pojazdu działa z pewną siłą na sieć jezdną. Efektem tego oddziaływania jest uniesienie przewodu jezdnego w stosunku do jego położenia spoczynkowego. W uproszczeniu można stwierdzić, że wartość uniesienia przewodu jezdnego zależy od elastyczności sieci jezdnej i siły docisku odbieraka. Siła docisku zależy m.in. od charakterystyki statycznej i sił dynamicznych. Znając typ sieci, model odbieraka i prędkość pojazdu, można przyjąć, że uniesienie przewodu jest funkcją stanu technicznego odbieraka. Na podstawie obserwacji stopnia i charakteru wypierania przewodu jezdnego przez odbierak, możliwe jest więc określenie jego sprawności technicznej. Przeprowadzone badania symulacyjne, oparte na modelu matematycznym dynamicznych oddziaływań w układzie sieć-odbierak, potwierdziły tę tezę [19]. Wynika z nich m.in., że drgania samej sieci w małym stopniu wpływają na wartość maksymalną uniesienia przewodu - w chwili 
przejazdu odbieraka przez punkt pomiaru. Przyjęto ten parametr jako miarodajne kryterium oceny odbieraka, przy czym granice pasma wartości dopuszczalnych zależne są także od prędkości pojazdu, ze względu na składową aerodynamiczną siły. Badano przebiegi uniesienia dla różnych wartości parametrów: thumienia, sprężystości i sił tarcia $\mathrm{w}$ elementach konstrukcyjnych odbieraka. W przypadku zwiększenia siły tarcia znacząco maleje wartość uniesienia przewodu. Przy zmniejszonym tłumieniu rośnie amplituda drgań przewodu.

Schemat funkcjonalny opracowanego eksperymentalnego terenowego stanowiska pomiarowego przedstawiono na rys. 9 .

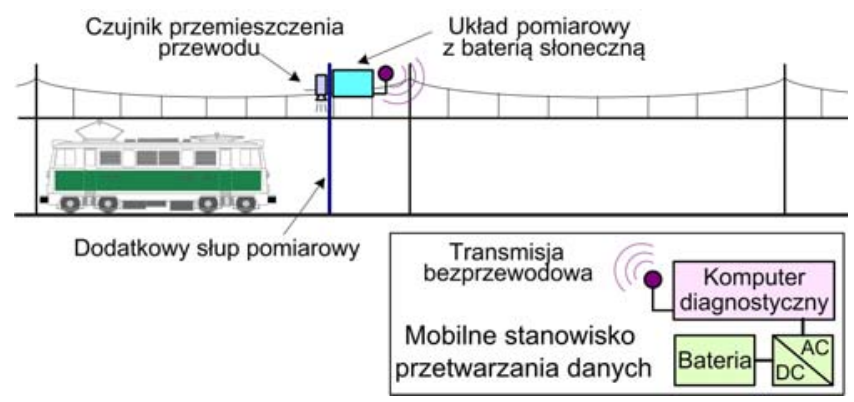

Rys. 9. Schemat funkcjonalny eksperymentalnego stanowiska monitoringu odbieraków prądu

Stanowisko składa się z dwóch zespołów: układu pomiarowo-rejestrującego oraz zespołu odbiorczoprzetwarzającego. Zespół pomiarowo-rejestrujący umieszczono na dodatkowej konstrukcji wsporczej w pobliżu zawieszenia sieci jezdnej. Ze względu na wysokie napięcie sieci jezdnej układ wyposażono w autonomiczne zasilanie $\mathrm{z}$ ogniwem fotowoltaicznym $\mathrm{i}$ zestawem akumulatorów z przetwornicą, oraz w bezprzewodową transmisję danych. Wszystkie elementy umieszczone są na wysięgniku, do którego przymocowano skrzynię z rejestratorem cyfrowym i układami zasilającymi, antenę do bezprzewodowej transmisji danych w standardzie WLAN oraz wspornik do mocowania przetwornika pomiarowego - laserowego przetwornika przemieszczenia. Przetwornik mierzy odległość do płytki refleksyjnej, zamocowanej na przewodzie jezdnym. Zespół odbiorczoprzetwarzający ma charakter mobilny - może być umieszczony $\mathrm{w}$ dowolnym pomieszczeniu, zapewniającym niezakłócony odbiór danych; składa się on z punktu dostępowego sieci WLAN oraz zestawu komputerowego do analizy i wizualizacji zebranych danych. Dla miarodajnej oceny stanu technicznego odbieraków konieczne było przeprowadzenie skalowania układu pomiarowego. Posłużono się lokomotywą o odpowiednio wyregulowanych odbierakach, każdy o innej ściśle określonej wartości statycznej siły nacisku odbieraka. Dokonano kilku przejazdów przez stanowisko $\mathrm{z}$ różnymi prędkościami jazdy, rejestrując przebiegi uniesienia sieci. Skalowanie pozwoliło na określenie zależności maksymalnego uniesienia przewodu jezdnego od prędkości i siły statycznej odbieraka.

W okresie kilku miesięcy prowadzono pomiary dla pojazdów obsługujących normalny ruch rozkładowy. Prędkość pojazdu szacowano na podstawie analizy przebiegu uniesienia przewodu. Rysunek 10 przedstawia typowe przebiegi uniesienia przewodu podczas przejazdu pociagów $\mathrm{z}$ poprawnie wyregulowaną siłą nacisku odbieraków.

a)

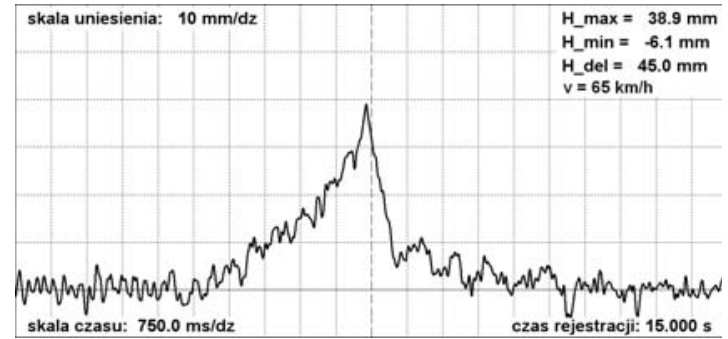

b)

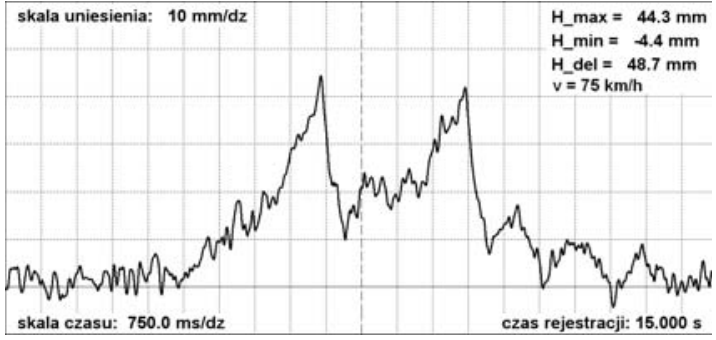

Rys. 10. Typowe przebiegi uniesienia przewodu przy prawidłowo wyregulowanych odbierakach: a) pociagg z lokomotywą jednoczłonowa, b) dwa zespoły trakcyjne

Stosunkowo często rejestrowano przebiegi uniesienia przewodu wskazujące na niewłaściwie wyregulowany nacisk statyczny odbieraka - obserwowano zarówno niewielkie wartości maksymalne uniesienia przewodu, wskazujące na zbyt niską wartość siły nacisku, jak i nadmiernie duże uniesienie. Na rys. 11 przedstawiono przykłady rejestracji takich odbieraków w ruchu liniowym na sieci. Obydwa dotyczą tego samego typu lokomotywy i odbieraka oraz zarejestrowane zostały przy zbliżonej prędkości jazdy.

a)

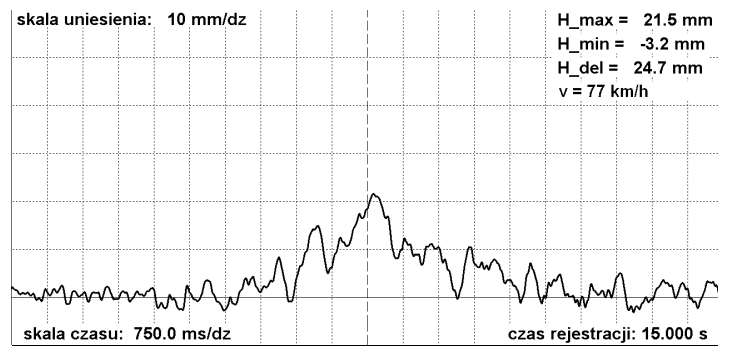

b)

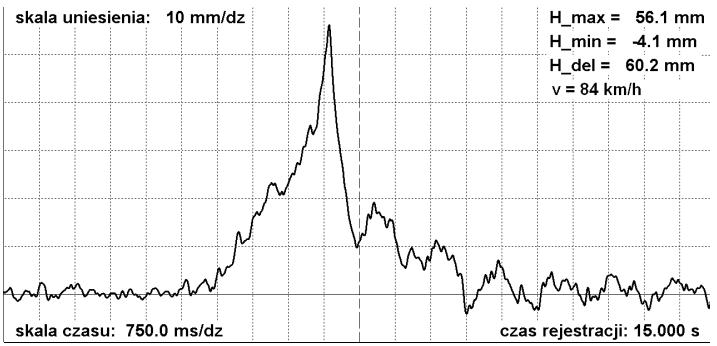

Rys. 11. Przebiegi uniesienia przewodu jezdnego przy źle wyregulowanych odbierakach lokomotyw przy prędkości ok. 80 $\mathrm{km} / \mathrm{h}$ : a) zbyt mały nacisk, b) zbyt duży nacisk 
Na rys. 12 przedstawiono statystyczne zestawienie wyników dla zarejestrowanych ok. 300 odbieraków wszystkie były odbierakami czteroramiennymi typu AKP4E lub 5ZL o normatywnej sile nacisku statycznego równej $90 \mathrm{~N}$. Zaledwie 56\% odbieraków mieściło się w paśmie odchyleń siły $\pm 10 \mathrm{~N}$, zaś dla $7 \%$ odbieraków błąd nastawy siły nacisku przekroczył $20 \mathrm{~N}$. Odbieraki te kwalifikowały się do naprawy lub regulacji. Można zatem stwierdzić, że eksploatacja stanowiska tego typu może w istotny sposób zmniejszyć liczbę uszkodzeń sieci i odbieraków, spowodowanych ich niewłaściwą regulacją.

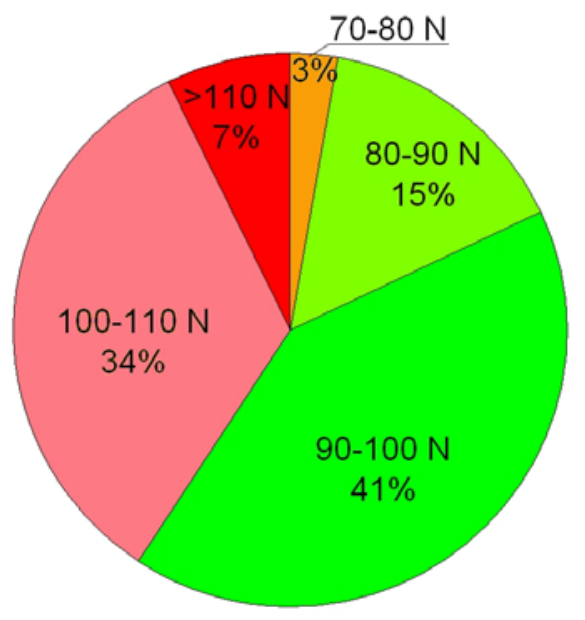

Rys. 12. Zbiorcze zestawienie wyników monitoringu

Obecnie na ukończeniu są prace przy wdrożeniu wersji użytkowej stanowiska. Ponieważ stanowisko umieszczono bezpośrednio na istniejącej bramkowej konstrukcji wsporczej sieci, a zatem na potencjale ziemi, laserowy czujnik przemieszczeń umieszczono ok. 2,5 m nad przewodem dla zapewnienia bezpiecznej odległości izolacyjnej, stąd charakteryzuje się on znacznie większym zakresem pomiarowym. Ponadto układ wyposażono w laserowy miernik prędkości i odległości pojazdu oraz kamerę, pozwalającą dokonać jednoznacznej identyfikacji pojazdu i odbieraka. Układ pomiarowy na konstrukcji wsporczej jest zasilany z zespołu akumulatorów, ładowanych poprzez ogniwa fotowoltaiczne oraz turbinę wiatrową. Wygląd pomiarowej części stanowiska na konstrukcji bramkowej sieci przedstawiono na rys. 13.

\section{Monitoring stanu nakładek ślizgowych odbie- raków prądu}

Eksploatowane do niedawna w Polsce nakładki pantografów kolejowych były wykonywane w postaci równoległych płaskich styków miedzianych. Wadą nakładek miedzianych jest ich stosunkowo duże zużycie ścierne. Nawet $\mathrm{w}$ przypadku stosowania smaru zużywają się także przewody jezdne. Na początku 2011 r. przeprowadzono kompleksową zmianę typu nakładek stykowych, stosowanych przez operatorów korzystających z infrastruktury PLK, z miedzianych

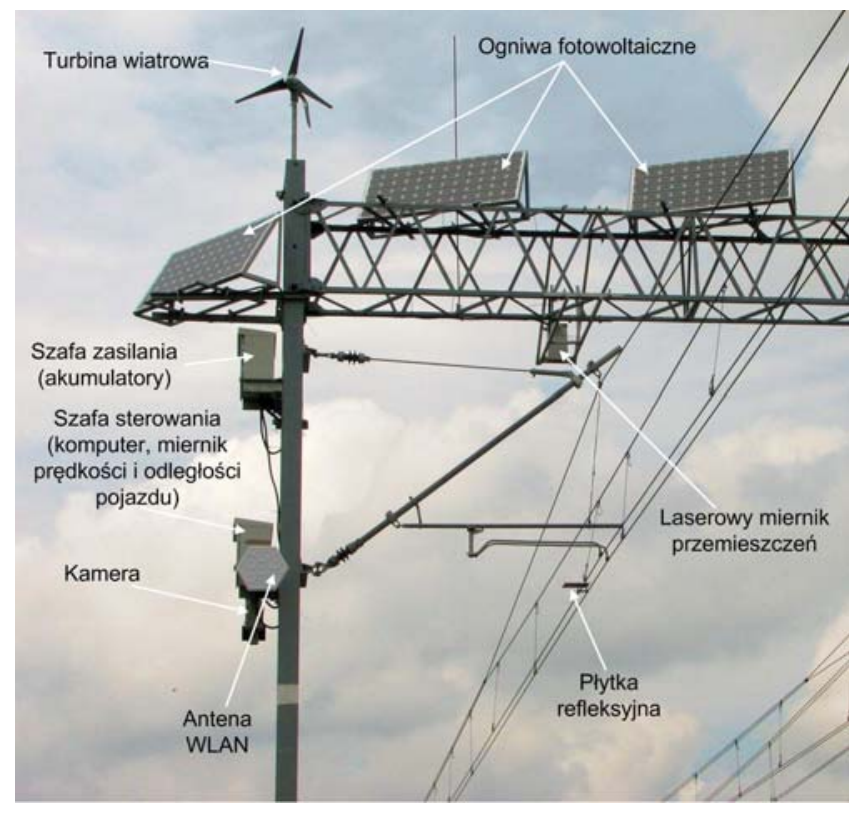

Rys. 13. Stanowisko monitoringu - wersja eksploatacyjna

na węglowe. Bardzo dobre właściwości smarne i elektryczne nakładek węglowych powinny zmniejszyć zużycie nakładek i sieci jezdnej [27].

Jednakże nakładki węglowe mają mniejszą wytrzymałość mechaniczną - występują pęknięcia, a nawet odrywanie się części nakładki od podłoża. Także zużycie nakładek jest intensywniejsze w okresie zimowym. Zaobserwowano również zmianę poziomu chropowatości i zarysowań wzdłużnych pod wpływem iskrzeń i łuku. Ma to istotne znaczenie w systemie zasilania trakcyjnego napięciem stałym, gdzie występują duże wartości prądów. Wraz z wprowadzeniem nakładek węglowych istnieje potrzeba opracowania nowych metod diagnostyki tego istotnego elementu toru zasilania pojazdu. Celem diagnostyki jest wykrycie uszkodzonych i nadmiernie zużytych nakładek zestyków ślizgowych.

Obecnie trwają prace nad wykorzystaniem do tego celu analizy obrazu 3D, ukierunkowanej na ocene stanu technicznego nakładki ślizgowej, w szczególności jej grubości, a także na wykorzystanie składowej intensywności i/lub stopnia rozproszenia bądź pochłaniania światła o określonej długości fali do oceny stanu jej powierzchni. Proponowane rozwiązanie opiera się o wykorzystanie nowych metod pomiarowych $\mathrm{z}$ obrazowaniem trójwymiarowym, które jak dotąd nie było stosowane do diagnostyki technicznej, zwłaszcza obiektów będących w ruchu i pracujących w trudnych warunkach środowiskowych. Istnieja pewne opracowania dotyczące inspekcji stanu torowiska (podkładów, mocowań, zużycia szyn itp.). W tych systemach możliwa jest akwizycja obrazu trójwymiarowego $\mathrm{w}$ odstępach milimetrowych dla prędkości jazdy rzędu $50 \mathrm{~km} / \mathrm{h}$ [38]. Rozważany w realizowanym projekcie*) problem związany $\mathrm{z}$ analizą obrazu 3D poruszającego się obiektu jest zagadnieniem nowym. Koncepcję stanowiska pomiarowego przedstawiono na rys. 14. 
Oprócz analizy teoretycznej i badań laboratoryjnych, zamierza się przeprowadzić testy diagnostyczne nakładek pojazdów poruszających się na linii kolejowej. Pozyskane dane pozwolą na określenie kryteriów oceny stanu technicznego nakładek ślizgowych odbieraków oraz możliwe będzie przeprowadzenie analizy porównawczej wyników uzyskanych na tych samych odbierakach prądu. Aktualnie prowadzone wstępne prace dotyczą projektu stanowiska badawczego oraz obsługi interfejsu kamery 3D. Istotne jest pozyskiwanie z kamery dużej liczby danych pomiarowych i ich transmisji oraz rejestracji. Przetwarzanie danych odbywać się będzie na stanowisku wyposażonym w komputer o stosunkowo dużej mocy obliczeniowej. Wyniki badań będą publikowane na następnych konferencjach.

\section{Wnioski końcowe}

Przedstawione w artykule wyniki eksperymentalnych prac badawczych i rozwiązań wdrożonych w PKP pozwalają na stwierdzenie, że nowoczesne, w pełni automatyczne i skomputeryzowane systemy diagnostyki sieci i odbieraków prądu są bardzo użyteczne w praktyce eksploatacyjnej. Główną ich zaletą jest to, że umożliwiają kontrolę stanu technicznego urządzeń ze znacznie większą częstotliwością i dokładnością przy mniejszym koszcie w stosunku do metod tradycyjnych. Zwiększa to prawdopodobieństwo wykrycia uszkodzenia lub znacznego rozregulowania układu, zanim spowoduje ono poważniejsze następstwa.

Analizując kolejne wyniki badań konkretnej lokomotywy, możemy często zaobserwować postępujące zmiany parametrów odbieraków prądu. Badanie odbieraków prądu w warunkach lokomotywowni obecnie przeprowadza się w praktyce co ok. 25 dni. Zastosowanie terenowego stanowiska do diagnostyki technicznej odbieraków prądu umożliwia przeprowadzenie badań przed każdym wyjazdem lokomotywy, a zatem znacznie częstsze niż dotychczas sprawdzanie nacisków i charakterystyki pantografu.

Awarie powstałe $\mathrm{z}$ powodu niewłaściwego utrzymania sieci mogą mieć poważne skutki techniczne, ruchowe, osobowe i finansowe. Wady techniczne sieci są wykrywane przez system DST. Podczas wieloletniej eksploatacji pozwoliły one wykryć szereg przypadków niewłaściwej regulacji sieci [13].

Przeprowadzone badania doświadczalnego stanowiska monitoringu odbieraków wykazały, że przypadki niewłaściwej regulacji odbieraków prądu nadal często występują w ruchu kolejowym. Opracowane stanowisko umożliwia wykrycie pojazdu z niesprawnym odbierakiem prądu, również w sytuacji, gdy uszkodzenie nastąpiło już po wyjeździe z lokomotywowni. Wdrożenie systemu monitoringu, które jest obecnie $\mathrm{w}$ trakcie realizacji, umożliwi zwiększenie poziomu bezpieczeństwa w ruchu kolejowym i-po średnio - obniżenie kosztów eksploatacji taboru i sieci trakcyjnej. W wersji użytkowej zostało ono doposażone w system wykrywania, identyfikacji i pomiaru prędkości pojazdu, co pozwoli na całkowicie automatyczną i niemal bezobsługową prace stanowiska w trybie ciagłym.

Podjęte badania nad monitoringiem stanu nakładek ślizgowych stwarzają szansę opracowania nowoczesnego układu wykrywania uszkodzeń w tym zakresie, które - jak pokazuje praktyka eksploatacyjna zdarzają się stosunkowo często podczas ruchu pojazdu.
*) Projekt został sfinansowany ze środków Narodo- wego Centrum Nauki

\section{Bibliografia}

[1] Allotta B., Pugi L., Fabio B.: Design and Experimental Results of an Active Suspension System for a High-Speed Pantograph. IEEE/ASME Transactions On Mechatronics, Vol. 13, No. 5, October 2008.

[2] Balestrino A., Bruno O., Landi A., Sani L: Active controls and non-invasive monitoring for high speed trains. IFAC 2005.

[3] Balestrino A., Bruno O., Landi A., Sani L: Innovative Solutions for Overhead CatenaryPantograph System: Wire Actuated Control and Observed Contact Force. Vehicle System Dynamics, 33 (2000), pp. 69-89.

[4] Blug A., Baulig C., Wolfelschneider H., Hofler H.: Fast Fiber Coupled Clearance Profile Scanner using Real Time 3D Data Processing with Automatic Rail Detection. 2004 IEEE Intelligent Vehicles Symposium, University of Parma, Parma, Italy June 14-17,2004.

[5] Borromeo S., Aparicio J. L., Martinez P.M.: MEDES: contact wire wear measuring system used by the Spanish National Railway (RENFE). Proc. Instn Mech. Engrs Vol. 217 Part F: J. Rail and Rapid Transit 2003.

[6] Borsiak J. i inni: Stanowisko do badań pantografów przeznaczone do eksploatacji w procesie produkcji oraz utrzymania taboru kolejowego $i$ tramwajowego-założenia. TTS 1-2/2011

[7] Bucca G., Collina A.: A procedure for the wear prediction of collector strip and contact wire in pantograph-catenary system. Wear 266 (2009)

[8] Chugui Yu. V., Verkhogliad A. G., Bazin V. S., Kalichkin S. V., Kalikin V. E., Makarov S. N.,. Vykhristyuk I. A: Optical remote dimensional inspection of live contact wire in train's electrosupply network. Measurement Science Review, Volume 8, Section 3, No. 2, 2008 
[9] Collina A., Facchinetti A., Fossati F., Resta F.: An Application of Active Control to the Collector of an High-Speed Pantograph: Simulation and Laboratory Tests. Proceedings of the 44th IEEE Conference on Decision and Control, and the European Control Conference 2005 Seville, Spain, December 12-15,

[10] Cumpstey D. E., Taylor P. J., Mansell P., John I.: Condition Indicator System for Wearable Elements, European Patent EP0269307, June 1, 1988.

[11] Diana G., Fossati F., Resta F.: High Speed Railway: Collecting Pantographs Active Control and Overhead Lines Diagnostic Solutions. Vehicle System Dynamics, 30 (1998), pp. 69-84

[12] Ferguson, I. C.: Improvements in or Relating to Current Collectors for Use with Overhead Power Cables, UK Patent GB1374972, Nov. 20, 1974.

[13] Giętkowski Z., Karwowski K., Mizan M.: Diagnostyka sieci trakcyjnej. Gdańsk: Wydaw. PG, 2009 / Biblioteka Cyfrowa Politechniki Gdańskiej, ISBN 978-83-7348-294-4.

[14] Hamey L. G. C., Watkins T., Yen S. W. T.: Pancam: In-Service Inspection of Locomotive Pantographs. Digital Image Computing Techniques and Applications, 9th Biennial Conference of the Australian Pattern Recognition Society on, 2007.

[15] http://www.micronova.it

[16] http://www.selectravision.com

[17] Jovanovic S.: Modern railway infrastructure asset management. Proceedings of the 24th Southerm African Transport Conference 2005.

[18] Judek S., Sawczuk M., Więckiewicz D.: Wizyjny system pomiaru wybranych parametrów odbieraków pradu. Technika Transportu Szynowego - nr 3/2010, s. 61-64, ISSN 1232-3829.

[19] Karwowski K., Mizan M.: Technical diagnostics and monitoring of traction current collectors. Modern Electric Traction: Power Supply / Eds. K. Karwowski, A. Szelag. Gdańsk University of Technology, 2009, s. 151-167, ISBN 83-911669-7-X.

[20] Karwowski K., Mizan M.: Monitoring parametrów technicznych odbieraków pradu w warunkach ruchowych na linii kolejowej. Pomiary Automatyka Kontrola - Vol. 55, nr 12 (2009), s. 1012-1016, ISSN 0032-4110.

[21] Kießling F., Puschmann R., Schmieder A.: Contact lines for electric railways. Siemens, Publicis, Munich 2001, ISBN 3-89578-152-5.

[22] Kim J. -W., Chae H. -C., Park B. -S., Lee S. -Y., Han C. -S., Jang J. -H.: State sensitivity analysis of the pantograph system for a high-speed rail vehicle considering span length and static uplift force. Journal of Sound and Vibration 303 (2007) 405-427

[23] Kin E. C. W.: Pioneer Design in Automatic Pantograph Wear Monitoring, Engineering Integrity, 19, 2006, pp. 12- 17.

[24] Landi_A., Menconi L., Sani L.: Hough transform and thermo-vision for monitoring pantograph-catenary system. Proc. IMechE Vol. 220 Part F: J. Rail and Rapid Transit41/2006.

[25] Lin Y. C., Lin C. L., Yang C. C.: Robust Active Vibration Control for Rail Vehicle Pantograph. IEEE Transactions On Vehicular Technology, Vol. 56, No. 4, July 2007
[26] Luna Vaì zquez C.A., Mazo Quintas M., Marroì n Romera M.: Non-contact sensor for monitoring catenary pantograph interaction. Industrial Electronics (ISIE), 2010 IEEE International Symposium

[27] Majewski W., Rojek A.: Badanie naktadek węglowych pantografów AKP4E i 5ZL na sieci PKP. 7 Międzynarodowa Konferencja Naukowa Nowoczesna Trakcja Elektryczna w Zintegrowanej Europie XXI wieku MET'2005 Warszawa.

[28] Moretti M., Triglia M., Maffe G.: ARCHIMEDE The First European Diagnostic Train for Global Monitoring of Railway Infrastructure. University of Parma, Italy June 14-17, 2004.

[29] Östlund S., Gustafsson A., Buhrkall L., Skoglund M.: Condition monitoring of pantograph contact strip. Railway Condition Monitoring, 2008 4th IET International Conference

[30] Pazdro P., Karwowski K., Leman S., Mizan M., Reducha W.: Terenowe stanowisko pomiarowe do diagnostyki technicznej odbieraków prqdu. Technika Transportu Szynowego - nr 3/2008, s. 44-49, ISSN 1232-3829.

[31] Pazdro P., Mizan M., Skibicki J.: Diagnostyka techniczna zawieszenia ślizgacza trakcyjnego odbieraka pradu. Pomiary Automatyka Kontrola Vol. 53, nr 4 (2007), s. 56-59, ISSN 0032-4110.

[32] Resta F., Collina A., Fossati F.: Actively controlled pantograph: an application. 2001 IEEE/ASME International Conference on Advanced Intelligent Mechatronics Proceedings, 8-12 July 2001, Como, Italy

[33] Richter U., Schneider R.: Automatische optische Inspektion von Oberleitungen. Elektrische Bahnen Nr. 1-2, 2001.

[34] Shing A., Pascoschi G.: Contact Wire Wear Measurement and Data Management. IET International Conference on Railway Condition Monitoring. The Institution of Engineering and Technology International Conference on Volume, Issue 29-30 Nov. 2006.

[35] Wenrui Jin, Xingqun Zhan, Benhe Jiang: Noncontact Rail-wear Inspecting System Based on Image Understanding. Proceedings of the 2007 IEEE, International Conference on Mechatronics and Automation, August 5 - 8, 2007, Harbin, China

[36] Wu T. X., Brennan M. J.: Active vibration control of a railway pantograph. Proc Instn Mech Engrs Vol 211 Part F F01097 (C) IMechE 1997.

[38] Zimmert G.: Dynamisches Verhalten der Oberleitung für $350 \mathrm{~km} / \mathrm{h}$ auf der neuen Strecke Wuhan Guangzhou. EB 108 (2010) Heft 4

[38] Zaskakujace możliwości nowoczesnych systemów wizyjnych. Control Engineering Polska. Nr 10 (43). Rok V, 2007. 